\title{
CONCEPTUAL ART IN TURKEY: CENGIZ ÇEKIL
}

\author{
F. Nazlı Suyum ${ }^{1}$ and Canan Zöngürr ${ }^{\star 凶}$ \\ ${ }^{1}$ Mugla Sitki Kocman University, Social Sciences Institute, Graduate Student, Mugla, Turkey \\ ${ }^{2}$ Mugla Sitki Kocman University, Bodrum Fine Arts Faculty, Bodrum, Mugla, Turkey
}

\section{Review Article}

PII: S238315532000004-9

Received: 22 Apr. 2020 Revised: 30 May. 2020 Published: 15 Jun. 2020

Corresponding author: E-mail: cananzongur@mu.edu.tr

\begin{abstract}
Conceptual Art emerged in the 1960s and displayed an entirely idiosyncratic structure as compared to those years' prevailing form pursuits. It involved the art object in an intellectual process rather than a structural process. This very understanding, which keeps its distance from art object and prioritizes the artists' ideas, enables the artists to express themselves by exploiting all kinds of materials. Similar tendencies became manifest in Turkey during the end of 1970s. Some Turkish artists returned back to the country after completing their studies abroad and with the occasion of biennials they became effective in the scene of conceptual art. Each of these artists produced individually important conceptual artworks, which represent their own time. This research is focused on Cengiz Çekil, who is an important representative of Conceptual Art in Turkey, the period when Conceptual Art emerged, its leading artists back then and their works. Furthermore, this paper includes the examination of Cengiz Çekil's works which carry the social and cultural traces of his time, his interviews, art perception and both his position and importance in today's Conceptual Art. Based on the existing examples the literature has been reviewed and the artist's works have been analysed. When it comes to Conceptual Art in Turkey, one of the first names that come to mind is Cengiz Çekil. For, by means of the unique mentality he demonstrates through his 'new' and astonishing style, he has been one of the most prominent artists in Turkish art history.
\end{abstract}

KEYWORDS: Cengiz Çekil, Conceptual Art, Sculpture, Installation.

\section{INTRODUCTION}

Conceptual Art emerged in 1960s as a striking art style among others, which were concentrated on different artistic pursuits and trials. Nevertheless, long before, in 1913, Marcel Duchamp had already explored the readymade. By challenging his day's art communities through his unconventional and new artistic approach, Duchamp brought the art works' ideas, images, forms, aesthetical concerns and messages forward. In that period, anti-Minimalists had embarked and concentrated, in a similar vein, on the 'language' of the artworks in relation with art galleries, which are common venues for the artists and their works to manifest their specific ideas. The aim was to deliver an information through a visually well-conceived and strong 'installation'. All of these attempts, undertaken by artists who focused on the conceptual nature of artworks, triggered new and investigative declarations.

In parallel with this objective, the artists, who in terms of Modern Art are Conceptualists, attached great importance to printed texts, photographs etc. due to these materials potential to convey the artworks' messages directly and clearly to the audience [1].

American artist Joseph Kosuth stated that it is necessary to liberalise art, rather than imprisoning it into concrete forms. Art has its own justifications and in order to give the human spirit the opportunity to reveal itself, the unique art perceptive is necessary. He also argued that Duchamp's Readymades changed the history of art completely by shifting significance from 'appearance' to 'concept' [1].

Conceptual Art examples started to emerge during the mid-1960s. However, much earlier, in 1952, John Cage asserted within his integrated sound field' that music includes all kinds of sounds, including any kind of sound that does not belong to music and even the absent sound. He observed that while sound has a pitch, loudness and duration, silence has only a duration. During the performance of his silent composition called Four Minutes Thirty Three Seconds (4'33), he was just present, neither doing anything nor producing a sound. Inspired from Robert Rauschenberg's 1951 dated works called 'White Paintings', Cage eliminated everything but the random noises of the environment and duration (common traits of both sound and silence). Cage's actual intention in this work was the individuality of the observer's experience [2].

As an art phenomenon of the 1960s, Conceptual Art is similar to Minimalism, however, it by-passes the content and represses the aesthetical elements of the art. This conscious contradiction, which arises 
from Dadaist approach, paves the way for some stimulating paradoxes. When Conceptual Artworks come together with the audience, (especially in deliberate places like galleries), it soon starts to evoke traditional forms of art, since aesthetic expectation and imagination associate each other. On the other hand, brushing the aesthetics aside by following in Minimalism's footsteps does not mean that the artists need less time to generate their artworks compared to Renaissance artists' efforts. And then again, all creative processes require a certain and conscious performance [3].

The expression 'Conceptual Art' was invented in 1967 by Sol LeWitt to summarize these kind of works' intention: Rather than engaging the eye or feelings of the audience, Conceptual Artwork's raison d'être is to urge the viewers to think. Since "the idea becomes the machine that makes the art," planning and decisions should come before all else, which then relegates execution to the condition of "a perfunctory affair." LeWitt added that "ideas may (even) be stated with numbers, photographs, or words or any way the artist chooses, the form being unimportant" [1].

Critics accepted that LeWitt has always embraced an irrational, spiritual and mystical verbiage, and that his main intention by inventing 'Conceptual Art' is to subvert Minimalism. In his 1966 dated manifesto 'Sentences on Conceptual Art' he lended credence to critics by mooting that "conceptual artists are mystics rather than rationalists. They leap to conclusions that logic cannot reach" [4].

Conceptual Art focuses mostly on the artistic experience itself and this experience's theoretical elements, in such a way that referring to the object becomes unnecessary. In 1969, Vito Acconci for instance tracked individuals through the streets within his work called 'Following Piece', aiming to link the viewer to an anonymous experience (individual, viewer, photographer, Acconci) through the candid shots his photographer provided [2]. Acconci stated that he had been an inactive receiver of an individual's space and time. One of his chases ended after nine hours when the person he followed entered a theater showcasing the movie 'Paranoia' [2]. By eliminating the aesthetical object in Conceptual Art in the interest of manifesting his own idea, the artist has been able to experience a number of production methods.

American artist Joseph Kosuth is also one of the most important conceptual artists. He is a supporter of the movement, which tries to reidentify the constituents of an artwork. By questioning the traditional art forms and the assumptions that accompany these forms, he uses his ideas and language as a material [5]. Arthur C. Danto calls Joseph Kosuth in his book 'After the End of Art' as one of the few people who during the 6os and 705 produced artworks that analyse the philosophy of art. In Kosuth's 'Art After Philosophy' published in 1969, he stated that art invites us to an intellectual thinking and its aim by doing so is not to recreate an artwork but instead to understand philosophically what art is [6].

Joseph Kosuth's "One and Three Chairs" is one of the most important examples of Conceptual Art. In this work, a chair stands alongside a photograph of a chair. And next to the actual chair there is a photograph of a verbal dictionary explanation of the word 'chair' hung on the wall. Eventually all of these three objects represent the chair, yet with different codes. Thus exhibiting these verbal, visual and representative codes of a single object together has been the smartest way to bring the connection and irrelevant connection between the 'referent' and the 'signifier' into question [1].

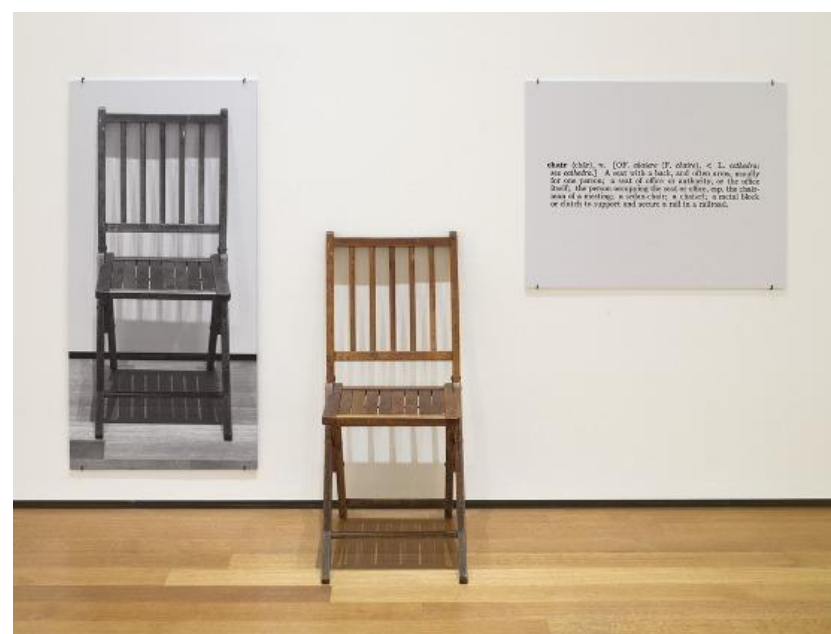

Figure 1. Joseph Kosuth, 'One and Three Chairs' 1965, folding chair, photograph of a folding chair, photograph of the lexical meaning of chair. Chair: $82 \times 37.8 \times 53 \mathrm{~cm}$, folding chair's photograph: $91.5 \times 61.1 \mathrm{~cm}$, photograph of the chair's lexical meaning: $61 \times 61.3$ [7].

The Conceptual Art understanding of the 1960s and 1970s aimed to overcome the conventional expectation from art, which eventually is not obliged to produce aesthetically pleasurable forms. Some of the early Conceptual Artists adopted an understanding in which the artwork is useless, if it is not able to preoccupy the viewer. Conceptual Art is usually considered as 'mind's art'. Its representatives emphasized its cognitive value rather than its aesthetical value [8]. 
Although in this art circle technology seems not to be essential, the attribution to technology paved the way for the faith in artistic process. The main characteristic of contemporary art was not the design of the venue anymore, it was instead, the interactivity between viewer, artist, main topic and content. Since then, the description of an art object has been connected to its efficiency in using the venue. Both the limits of structural and artistic forms have become unclear; the artist preferred to exhibit her/himself (the image of self-consciousness) [9]. The artist's inner-position had never converted into such a direct material.

Yet another outstanding Conceptual Artist is Joseph Boyes. Apart from his interesting life story, participating in Fluxus and producing conceptual artworks by using ordinary matters like fat, felt, etc., transformed him into the most conspicuous artist of this movement. Beuys said: "I tried to separate the concept of plastic into three simple objects. But this is not solely limited with objects that are physically perceivable. The same thing applies to plastic materials which are invisible. I start using unspecified materials like fat and soil, and through a certain action, I reconstruct a new form from these" [10].

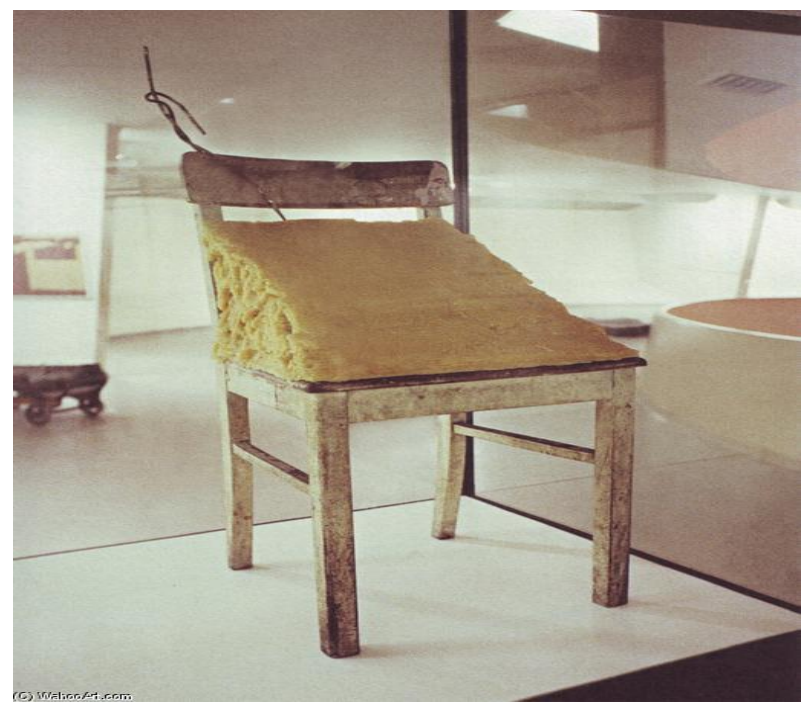

Figure 2. Fat Chair, 1964, Wooden Chair, Animal Fat [11]

Joseph Beuys' Fat Chair transformed two ordinary materials into an open-ended metaphor. In 1964 he exhibited this work in a glass case and let it undergo a natural process of decay until 1985 . During this process the fat decomposed in such an extent that it evaporated and nearly disappeared. The main organic compounds he used in his artwork let the audience identify themselves with these materials and experience the temporarity of life and physical perishment of humans in the course of time [11]. The chair is consonant with human body and living style. Fat on the other hand, experiences radical transformation with a tint change in temperature and thus indicates the chaos. For Joseph Beuys everything is changing and the chaos triggered by this reality may have a remedial effect. Beuys has seen in the transformation of fat and continuous formal changes that almost remind the spiritual alteration potential of humans, an analog of spirituality [2].

Based on this artistical environment, period and approaches, this research paper investigates the moral of the period when Conceptual Art emerged and its leading artists and in this context, it examines Cengiz Çekil's, one of the most significant representatives of Conceptual Art in Turkey, works and art perception. And it is also aimed to lay emphasis on his conceptual works' place and significance in Turkey's contemporary art and herewith to contribute the related literature.

\section{CENGİZ ÇEKIL IN THE CONTEXT OF CONCEPTUAL ART}

Conceptual Art appeared in Turkey as from the end of $70 \mathrm{~s}$ and became prevalent within the art environment of $80 \mathrm{~s}$. As one of the leading artists of Turkish Conceptual Art, Cengiz Çekil created remarkable artworks in this field and has been an important representative of conceptual art, both in Turkey and abroad. He was born in Niğde-Bor in 1945. He graduated from Ankara Gazi Education Institute's Art Teaching department in 1968. Between 1970 and 1975 he completed his Sculpture/Modelling study in Paris, founded by the ministry. In 1978 he started working in Ege University's Faculty of Fine Arts department as research assistant. Çekil regarded the sculptures he produced in Paris as his first works [12]. He launched his first solo exhibition 'Réorganisation pour une Exposition' (Reconfiguration for an Exhibition) in Paris.

During one of his interviews with Necmi Sönmez, the artist stated that he was amazed by Beuys' and Duchamp's works, and that he had conceptualized his works under their influence. He asserted that they are the benchmarks of contemporary art and on all occasions he uttered his admiration for both of them [12].

'Direnç: Ölü Bir Somyanın Anısına' (Resistance: in Memory of a Dead Mattress), one of the artist's most known works (Figure 3) consists of a used, dumped, rusted bed, carrying on the middle an 
amiant band and above this a resistance lying. $\mathrm{He}$ spread a piece of white fabric, a material that will become a frequently used material in his subsequent works, under this installation. This white fabric reminds a deathbed, a shroud, on which a dead body lyes. This glowing hot resistance, dividing the bed in to two symmetrical pieces, symbolizes the ablaze resistance against death. The artist has never been unconcerned about the goingson around him. This work, which he produced during the time he lived in Paris, refers at the same time to 'La résistance', the name of an anti-fascist resistance which emerged against the Nazi occupation in France during World War II. Çekil's efforts to exhibit more than one work together started with his exhibition at Beaux-art in Paris. In one of its small galleries designated for small-scale exhibitions he exhibited four of his works together: Iron Earth Copper Sky, Resistant Areas, The Heating Coil and Resistance in a Capillary Long Tube, Resistance: in Memory of a Dead Mattress [13].

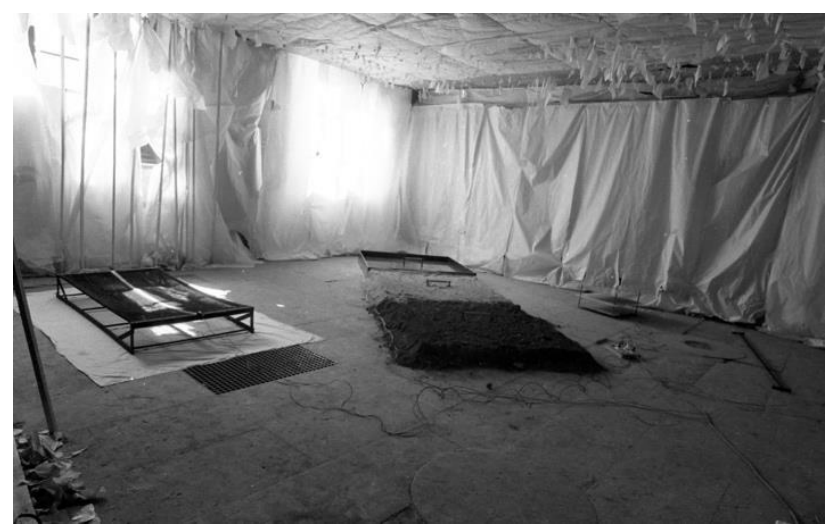

Figure 3. Private Exhibition of a Group of Works at École des Beaux-Arts: Resistance: in Memory of a Dead Mattress (1974), Iron Earth Copper Sky (1975), Resistant Areas (1975), The Heating Coil and Resistance in a Capillary Long Tube (1975). From SALT Research's Cengiz Çekil Archive [14]

The conceptual artist may intend to fix the emphasis for materiality or may want to use it paradoxically. Whatever the intention is, an art approach of this nature requires the highest economy of materials. If an idea is better presented in two dimensions, a three dimensional application should be out of question. The ideas may be expressed through numbers, photographs, words or any other medium the artist prefers, the object/material stands beside the point [15]. In this context Cengiz Çekil generated his concepts without focusing on a particular material or dimension.
Another well-known work of the artist is "The Yellow Rubber" (Figure 4). The work consists of a canvas, lace and a hook. The lace and colour on the background of a 144 pieces of flipped canvases fall within the system of colours and shapes Çekil rebuilt, and display formal diversities. The wooden panel represents the Ottomans' civil architectural oriel windows, which protrude from the main walls of the buildings without letting the people in the house step outside. According to the artist, framing the work refers to a kind of introvertedness, motivated by the necessity of upholding the 'honour' of people living in the house. Both the rubber which is commonly used in house cleaning and laces installed as a second background highlight the correlation between femininity and middle-class family. On the flipped surfaces of the canvases there are colour tones aking to human skin and tones like yellow, purple, grey and beige which look like bruises caused by physical abuse. These components together are representing the domestic violence which happen in a domestic setting and are usually concealed [1]. Through these works the artist emphasizes the cultural conservatism in Turkey, questions the traditions and at at the same time conveys his messages by exploiting conceptual art's freedom. And the immensity of materials he selected to create these artworks is utterly striking. As long as the artist's practice serves the concept, she/he is far more free in using different images and objects as compared to minimalists [16].

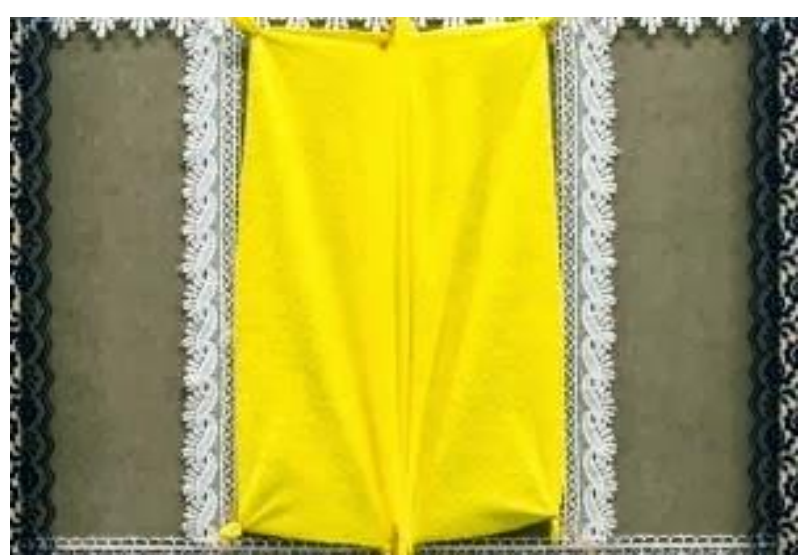

Figure 4. Yellow Rubber, 2013 [17]

In his exhibition "What Time Is It?" (Figure 5), he brought a series of his works together, which all concentrate on the same causal questions. This installation reminds of his work-series called 'Unlettered' (1975-1977) in which he used newspaper for the first time as a material. What Time Is It? displays for one week, newspaper sheets chosen from Hürriyet (a Turkish local paper), which 
consistently produces life-dominant dynamics and indicators identified by mainstream media. On these sheets behind a glass frame stands a semitransparent bold face 'What Time Is It?' question. Although it is hard to read the news behind this glass and letters, it is still visible. The abundance of images and words on the sheets points out the life's preciousness and fragility by countless repetition of the same question which interrogates the meaning of daily routine [13].

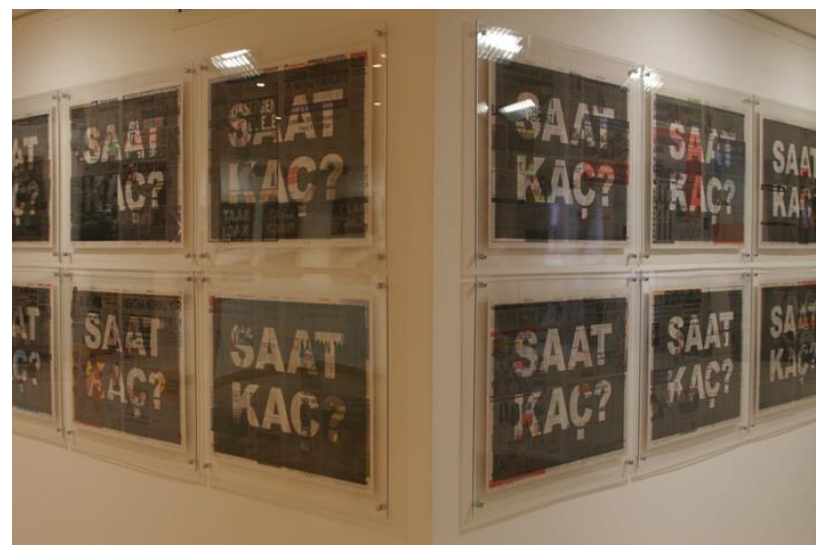

Figure 5. Cengiz Çekil, What Time Is It?, 2008 112 pieces, each piece $56 \times 75.7 \mathrm{~cm}$ [18]

The artist stamped every night before sleeping on a diary he bought in 1976 these statement: "I Am Still Alive" (Figure 6) and wrote the date. Representing as a diary the individual world/cosmology, this work entered the permanent collection of MoMa in 2011. The diaries that chronologically historicise a person's subjective adventure might be regarded as maps of the inner world. Through "I Am Still Alive", Cengiz Çekil mythicise his inner world which has to squirm before the external world. The Left vs. Right movements in Turkey in 1980s, current political conflicts and the tension generated by domestic policy led up to 12 September 1980 upheavals. As standing in the middle of such an insecure environment he actually, instead of meaning that he is still alive, wants to say that he coincidentally did not die that day. He summarized a pure world which sprouts in the middle of an internal conflict in which living is possible simply by accident [19].

Concepts and language are tightly knit, therefore, conceptual art is a practice that uses material to verbalize the concepts. While music consists primarily of tone, conceptual art's substance is language [16]. Thus Çekil's 'Diary' is a significant example in the context of language's potential to convey the notion.
The Japanese artist On Kawara's postcards and telegrams he daily sent to his friends and colleagues bearing messages like "I GOT UP", "I AM STILL ALIVE", "I Went I Met" and Çekil's Diary use similar languages to declare that they are still alive. While Kawara sent his messages to his friends, Çekil kept an abstract diary of the days he survived just for himself [13].

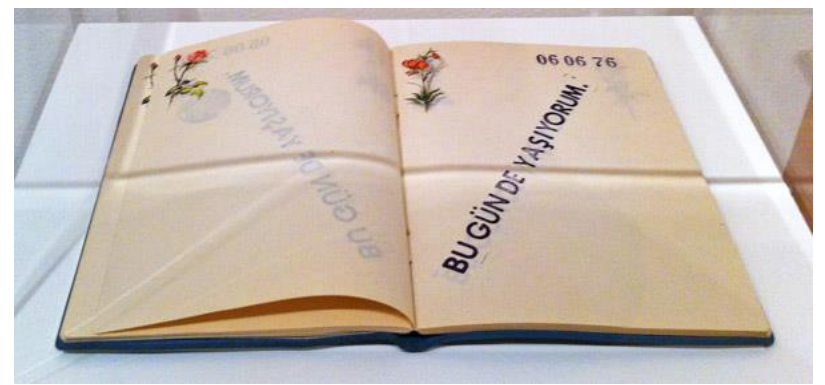

Figure 6. Cengiz Çekil “Diary”, 2011 [20]

In Çekil's works, spatial concerns stay in the background. For the installations of the artist, the environment serves merely as a platform to convey his opinions.

Harald Szeemann's famous exhibition "When Attitudes Become Form" (1969) has been a ground breaking curatorial application, manifesting the transformative nature of art language. Since the common trait of movements like Concept Art, Arte Povera, Fluxus etc. is that the artwork is merely a medium which conveys the energy, ideas and notions to the audience. Thereby, the artwork eludes materiality and experiences a transit journey. The materials Çekil has used in Paris reveal that they experienced the same transit journey with Szeemann's, and at the same time that he files with Joseph Beuys [13]. What makes Çekil successful in this field is his approach to material. Converting the right material into an art object can only be a good artist's achievement. The risk of appreciating the physicalism of a material on such a scale, lyes behind its potential to become the notion of the artwork [16].

Cengiz Çekil's first retrospective took place at Rampa in May-July 2010 and it has been the artist's largest exhibition. Curated by Vasif Kortun, this exhibition gathered all of the works the artist produced between 1974 and 2010 [14]. While participating a wide range of exhibitions at home and abroad, the artist served at the same as an academic and trained hundreds of students. The artist, who passed away on the 11th of November 2015, gained an important place in the history of Turkish Contemporary Art. 


\section{CONCLUSION}

This research quotes briefly the period when Conceptual Art emerged and the artistic environment in that period. Conceptual Art arose in 1960 s and has been an effective art approach until the end of 1980s. Within this subject, leading artists of this movement and their works have been mentioned. As one of the most effective names of Conceptual Art in Turkey, Cengiz Çekil's art perception and works have been examined. Through his 45 years art career he never gravitated to the vanity and dynamics of the art community. His main objective has always been to witness the recent past and hand it down to the future through images. He has quite a few works which he has not been able to exhibit due to various reasons. Granted that his art is an intellectual process, he never regarded art as a materialistic medium. In order to truly realize the art practice he narrated his life experience from a boy by exploiting unconventional materials. Prof. Dr. Fevziye Eyigör, member of Atatürk University, mentioned within her article published in the journal 'Sanat Dünyamı' (Our World of Art) that Çekil has been regarded as the representative of the hidden history of 1970 s current art and the 'Father of Contemporary Art' [21]. Cengiz Çekil soon comprehended the idea of Conceptual Art. During an interview with Necmi Sönmez he said that fleamarkets are like design museums and he provides the materials he needs from these markets. His work 'Diary', in which he included a big part of his life and ongoing since 1967, was selected for the permanent collection of MoMa, the most famous Modern Art Museum New York, shortly before his decease. These significant development is a testament to his international success. During the years he spent in Izmir both as an artist and as an academician, he trained a lot of artists and shared his perception of Conceptual Art with them. Cengiz Çekil is one the most significant and prominent artists in Turkish history of art.

\section{DECLARATIONS}

\section{Authors' Contributions}

F.N. Suyum is the lead author of the manuscript. She provided the background and the body of the work. C. Zöngür performed general overwide, analytical interpretation of the work, developed the abstract and conclusion sections. Both the authors directly participated in analysis of this study, and have read and approved the final version submitted.

\section{Competing interests}

The authors declare that they have no competing interests.

\section{REFERENCES}

[1] Hunter S, Jacobus J (1992). History of Modern Art. New York: The Times Mirror Company, p. 358-36o361. Google Scholar

[2] Fineberg J (2014). 1940'tan Günümüze Sanat. İzmir: Karakalem Kitabevi Yayınları. p.166. Google Scholar

[3] Janson HW (1995). History of Art. New York: Harry N. Abrams p.777-778. Google Scholar

[4] Heartney E (2008). Art \& Today, China: Phaidons, p.84. Google Scholar

[5] Collins J (2007). Sculpture Today, London: Phaidon, p.354. Google Scholar

[6] Danto AC (2014). Sanatın Sonundan Sonra, İstanbul: Ayrıntı Yayınları. p.37. Google Scholar

[7] MOMA.

(2020).

https://www.moma.org/collection/works/81435 (16.11.2020)

[8] Khan

Academy

(2020) https://www.khanacademy.org/humanities/art1010/conceptual-and-performance-art/conceptualperformance/a/joseph-kosuth-one-and-three-chairs (17.05.2020)

[9] Akay A, Zeytinoğlu E (1998). Kavramın Sinırlarında, İstanbul: Bağlam Yayıncılık, p.99. Google Scholar

[10] Beuys, C., Kounellis, J. Kiefer A., Cucchi, E. (2005). Bir Katedral İnşa Etmek, İzmir: Sel Yayıncılık, s.142. Google Scholar

[11] Smart History (2020). https://smarthistory.org/joseph-beuys-fat-chair/. (22.06.2020)

[12] Sönmez N (2008).Cengiz Çekil Bir Tanık. İstanbul: Yapı Kredi Yayınları, p.13, 15. Google Scholar

[13] Arıduru E, Elveren M (Ed.). (2020). Cengiz Çekil. İstanbul: Ofset Yapımevi, p.65, 256, 230.

[14] M-est (2020). https://m-est.org/2018/o7/11/oncengiz-cekil-resistance-in-memory-of-a-deadmattress-ii/ (16.11.2020).

[15] Harrison C (2011) Sanat ve Kuram 1900-2000: Değişen Fikirler Antolojisi. İstanbul: Küre Yayınları. Google Scholar

[16] Yllmaz M (2013). Modernden Postmoderne Sanat, Ankara: Ütopya Yayınevi. p.286. Google Scholar

[17] Blogspot. (2020). https://tristeshamshiny.blogspot.com/2013/o9/cen giz-cekil-sergisi-temizlik-beziyle.html (16.11.2020).

[18] Cultural Service (2020). https://sanat.ykykultur.com.tr/sergiler/cengiz-cekilsaat-kac-what-time-is-it (16.11.2020).

[19] Mercan IA (2015). Sanatta Kişisel Mitoloji ve Minörlük Olgusu. Sanat ve Tasarım Dergisi, p.143. Direct link; Google Scholar

[20] Kültür Servisi (2020). http://www.kulturservisi.com/p/sanatciakademisyen-cengiz-cekil-hayatini-kaybetti/ (16.11.2020). 
[21] Eyigör F (2016). Yanlış Zamanda Doğru Şeyler Söyleyen Sanatçı Figürü Olarak Cengiz Çekil. Sanat Dünyamı Kültür ve Sanat Dergisi, Sayı:
151, Mart-Nisan-2016, İstanbul, sf: 94-105 (ISSN 1300-2740-151). 